\title{
APPROXIMATION OF FIRE-RETURN INTERVALS WITH POINT SAMPLES IN THE SOUTHERN RANGE OF THE COAST REDWOOD FOREST, CALIFORNIA, USA
}

\author{
Gregory A. Jones ${ }^{1}$ and Will Russell ${ }^{2 *}$ \\ ${ }^{1}$ National Park Service, Golden Gate National Recreation Area, \\ 201 Fort Mason, San Francisco, California 94123, USA \\ ${ }^{2}$ Department of Environmental Studies, San Jose State University, \\ One Washington Square, San Jose, California 95192, USA \\ *Corresponding author: Tel.: +1-415-505-5800; e-mail: will.russell@sjsu.edu
}

\section{ABSTRACT}

A legacy of past fires is evident in the form of blackened basal hollows found throughout the southern range of the coast redwood (Sequoia sempervirens [D. Don] Endl.) forest. A deeper look reveals cambial scars dating back centuries, telling a story of low- to moderate-intensity fires that burned periodically across California's Central Coast bioregion. While attempts have been made to reconstruct the fire history of this forest type, estimates of the fire-return interval vary widely, and the relationship of the fire-return interval to varying cultural influences is not fully understood. We analyzed 373 fire scars from 70 cross-sections removed from stumps, downed logs, and live trees in the coastal Santa Cruz Mountains of California, USA, in order to estimate fire-return intervals (FRI) for individual trees, mean FRI across samples, and seasonality of historical fires. The mean FRI, averaged across point samples, was $60.6 \mathrm{yr}$ with a median of 40.1 yr. Fire scars were most prevalent in the dormant and latewood portions of annual growth rings. A sub-sample of 19 cross-sections, for which we were able to deter-

\section{RESUMEN}

El legado de fuegos pasados es evidente en forma de huecos ennegrecidos en la base de troncos encontrados en los bosques de sequoia roja (Sequoia sempervirens [D. Don] Endl.) de la región costera sur. Una mirada más profunda revela cicatrices en el cambium que datan de centurias pasadas, contándonos una historia de fuegos de baja a moderada intensidad que quemaron periódicamente a través de la Bioregión de la Costa Central de California. Mientras que varios intentos han sido realizados para reconstruir la historia del fuego en este tipo de bosque, estimaciones del intervalo de retorno varían ampliamente, y la relación entre el intervalo de retorno del fuego con influencias culturales variables no está completamente entendida. Nosotros analizamos 373 cicatrices de un total de 70 cortes transversales obtenidas de tocones, troncos caídos, y árboles vivos en la costa de las montañas de Santa Cruz en California, EEUU, para estimar los intervalos de retorno del fuego (FRI por sus siglas en inglés) para árboles individuales, el FRI promedio entre muestras, y la estacionalidad de fuegos históricos. El FRI medio, promediado de muestras puntuales, fue de 60,6 años con una mediana de 40,1 años. Las cicatrices de fuego fueron más prevalentes en las porciones latentes y de leño tardío de los anillos anuales de crecimiento. Una sub-muestra de 19 secciones transversales, 
mine approximate fire years, exhibited a high degree of variation between samples with individual tree FRIs ranging from $10.4 \mathrm{yr}$ to $128 \mathrm{yr}$. The mean FRI of $43.3 \mathrm{yr}$ was marginally higher for the pre-settlement period (1352 to 1849) compared to $30.7 \mathrm{yr}$ for the settlement period (1850 to 1924) and $32.3 \mathrm{yr}$ for the recent period (1925 to 2013). While our results suggest a longer estimate of fire-return intervals than previously documented for this forest type, high variation within and between samples clouded distinctions and illustrates a culturally constructed fire regime characterized by temporal and spatial heterogeneity. para las cuales nosotros pudimos determinar años aproximados de fuegos, exhibió un alto grado de variación entre muestras, con FRI de árboles individuales en un rango desde 10,4 hasta 128 años. La media del FRI de 43,3 años fue marginalmente más alta para el período de pre-colonización (1352 a 1849) comparado con 30,7 años para el período de colonización (1850 a 1924) y 32,3 años para el período reciente (1925 a 2013). Mientras que nuestros resultados sugieren un intervalo de retorno del fuego más largo que el previamente documentado para este tipo de bosque, una variación alta dentro y entre las muestras enmascararon las distinciones e ilustraron un régimen de fuegos construido culturalmente y caracterizado por una heterogeneidad espacial y temporal.

Keywords: anthropogenic, fire-return interval, historical variation, Sequoia sempervirens

Citation: Jones, G., and W. Russell. 2015. Approximation of fire-return intervals with point samples in the southern range of the coast redwood forest, California, USA. Fire Ecology 11(3): 80-94. doi: 10.4996/fireecology.1103080

\section{INTRODUCTION}

Recent wildfires in California's Central Coast bioregion have revived interest in the fire ecology of coast redwood (Sequoia sempervirens [D. Don] Endl.). The combination of fire- and rot-resistant properties and resiliency following disturbance (Ramage et al. 2010, Lazzeri-Aerts and Russell 2014) allows for the accumulation of fire scars in the blackened basal cavities that can persist for centuries (Jacobs et al. 1985, Stephens and Fry 2005). Although there is ample evidence of fire, estimates of the fire-return interval (FRI) vary significantly across the coast redwood range, and in the southern forests in particular (Davis and Borchert 2006, Lorimer et al. 2009). Relatively short mean FRIs (6.2 yr to $23.0 \mathrm{yr}$ ) were found by Finney and Martin (1992) on individual stumps, and mean FRIs ranged from $12.4 \mathrm{yr}$ to $16.3 \mathrm{yr}$ in a study by Stephens and Fry (2005). However, both of these studies focused on areas where Sequoia sempervirens tends to grow in isolated groves and are not necessarily representative of southern coast redwood forest as a whole, as fire frequencies found in these two studies are likely influenced by the fire regimes of adjacent grassland or chaparral communities (Stephens and Fry 2005). Brown et al. (1999) also found relatively short composite mean FRIs (7.7 yr to $13.0 \mathrm{yr}$ ) where coast redwood mixed with Douglas-fir (Pseudotsuga menziesii [Mirbel] Franco var. menziesii) in Point Reyes National Seashore, while a longer mean FRI of $21.7 \mathrm{yr}$ to $27.1 \mathrm{yr}$ was reported for Muir Woods National Monument in southwestern Marin County, where redwood is more contiguous across the landscape (Jacobs et al. 1985). Greenlee (1983) estimated a composite mean FRI of $45.4 \mathrm{yr}$ in a more representative coastal redwood stand in Big Basin Redwoods State Park, but the estimate was based on scars from only two stumps. 
Lightning-ignited fires are rare in coastal California due to a relatively low frequency of thunderstorms, as well as moist fuel conditions during the rainy season (Keeley 2005, Stephens and Fry 2005, Brown 2007, van Wagtendonk and Cayan 2008). As a result, most fires in the region have resulted from a variety of anthropogenic origins. To address the issue of human-induced burning, McBride (1983) proposed that fire history studies should include a classification of fire regimes based on land use. The redwood region, in general, supported high human population levels during the late Holocene (Sawyer et al. 2000), and Native Americans regularly used fire to manipulate coastal landscapes for a variety of purposes (Keeley 2002, Stewart 2002, Lightfoot and Parrish 2009). Considering that pre-colonial population densities on the central California coast were among the highest in North America (Milliken et al. 2009), it is likely that Native American burning practices altered the natural fire regime of the central coast (Keeley 2002).

The cultural use of fire during the Spanish and Mexican periods (1792 to 1848 AD) transitioned from indigenous management practices to fires resulting from logging and burning to improve livestock forage. Spanish loggers did not use fire intentionally, but accidental fires occurred on occasion. An early record of fire during the Spanish period (circa 1799) describes guards of enslaved "Indian axemen" who were injured by a fire in the woods (Brown 1966). There is also evidence that the Spanish stockmen engaged in intentional burning to extend areas of suitable forage and it is reasonable to assume that some of these intentionally set fires spread into heavier timber (Gordon 1996). Interestingly, the Spanish did engage in fire suppression activities to some degree as they routinely used military companies from the Presidio and Native American labor from the missions to suppress the fires (Brown 1966).

Logging and farming practices may have resulted in shorter fire-return intervals with the arrival of large numbers of Anglo-American homesteaders following the gold rush, which began in 1848 to the east in the Sierra Nevada. Homesteaders increased available farming and grazing acreage by using fire. Loggers set fires both to ease travel and log yarding, and to reduce the considerable quantities of slash that was generated during felling and limbing operations (Adams 1969). General apathy towards the practice of both indiscriminate and accidental burning eventually waned. Even before California officially achieved statehood, concerns over destructive fires in the redwoods were being voiced. Initially, the California state government avoided any state-sponsored fire control efforts, since it perceived fire prevention to be a personal responsibility. In the early part of the twentieth century, however, a series of subsequent acts institutionalized the system of fire suppression under the recently established (circa 1885) California Department of Forestry (Clar 1959). A series of fire lookout stations were built around the state to aid suppression efforts, the first being erected in the Santa Cruz Mountains on Mount Bielawski in 1922, in close vicinity to our study site (Clar 1959).

Stuart (1987) distinguished land use history for the northern part of the redwood range into the following periods: pre-settlement (pre1875), settlement (1875 to 1897), and post-settlement (1898 to 1940). California's central coast experienced a similar pattern of historical burning regimes originating from a variety of cultural land use practices. Greenlee and Langenheim (1990) classified five different fire regimes for the Santa Cruz Mountains: ancient (up to 11000 years before the present), aboriginal (11000 years before the present to 1792 A.D.), Spanish and Mexican (1792 to 1848), Anglo (1848 to 1929), and recent (1929 to the present). For this study, we used three cultural periods: pre-settlement $(<1849)$, which included both the Native American and Spanish periods; settlement (1849 to 1921), which included the early Anglo-American settlement and logging period; and recent (1922 
to 2013), the Anglo-American-dominated period with systematic fire suppression methods in place.

Our goals in conducting this study were to add to existing knowledge regarding coast redwood fire history in the southern part of the range by collecting and analyzing a broad range of samples from the Santa Cruz Mountains coastal biome. Fire scar analysis was used to estimate FRI for individual trees (point samples), approximate seasonality of past fires, and to estimate fire-return interval between three historical periods.

\section{METHODS}

Ring counts were used to approximately date fire scar samples extracted from live redwood trees, snags, downed logs, and stumps in the coastal Santa Cruz Mountains, California, USA. Fire scar records from individual trees were divided into two data types: 1) floating fire scar sequences - a decipherable temporal record without known beginning or end points (Kelly et al. 1994, Robichaud and Laroque 2008), based on fire interval data gleaned from ring counts; and 2) approximate chronologies-derived from cross-sections extracted from live trees and other samples with a known date of harvest. For the purpose of our analysis, results were grouped into comprehensive data (including both floating sequences and approximate chronologies) that were used to estimate the grand mean and median FRI, and approximate chronology data that were used to estimate FRI for three historical periods.

\section{Study Area}

We collected samples in the Santa Cruz Mountains north of Davenport, California, approximately $26 \mathrm{~km}$ northwest of Santa Cruz and $100 \mathrm{~km}$ south of San Francisco (Figure 1). Elevations within the study area range from sea level at the coast to $800 \mathrm{~m}$, with moderate to steep slopes ranging from $30 \%$ to $60 \%$. All cross-sections were taken within the Central Coast Hydrologic Basin, as defined by the California Department of Water Resources (2003).

The climate of the area is characterized as Mediterranean with cool wet winters and dry summers. Mean precipitation is approximately $107 \mathrm{~cm}$, falling mostly in the winter and spring in the form of rain with occasional snow on the higher peaks and ridges. Temperatures are generally mild, ranging from $6.5^{\circ} \mathrm{C}$ to $23{ }^{\circ} \mathrm{C}$. Fog tends to moderate the summer drought (Dawson 1998, Johnstone and Dawson 2010), and is considered a significant determinant in the distribution and inland extent of coast redwood (Cooper 1917).

Forest types in the area include stands dominated by Sequoia sempervirens and mixed stands with common associates such as Douglas-fir (Pseudotsuga menziesii), tanoak (Notholithocarpus densiflorus [Hook. \& Arn.] Manos), coast live oak (Quercus agrifolia Nee.), Pacific madrone (Arbutus menziesii Pursh), knobcone pine (Pinus attenuata Lemmon), California nutmeg (Torreya californica Torrey), and California bay (Umbellularia californica [Hooker \& Arnott] Nuttall).

Data were collected on lands owned and managed by Big Basin Redwoods State Park, Big Creek Lumber, the Sempervirens Fund, Skylark Ranch, Swanton Pacific Ranch, and San Vicente Redwoods (a 3453 ha parcel that was recently acquired by a consortium of San Francisco Bay area land conservation organizations). Both Swanton Pacific Ranch and Big Creek Lumber employ selective harvesting and uneven-aged forest management practices on their respective land holdings (Swanton $\mathrm{Pa}$ cific Ranch 2011). Swanton Pacific Ranch has conducted small prescribed burns for research purposes, but all unplanned ignitions in the area are aggressively suppressed. Big Basin State Park, adjacent to the study areas, has conducted modest prescribed fires periodically since 1978 (Biswell 1989). 


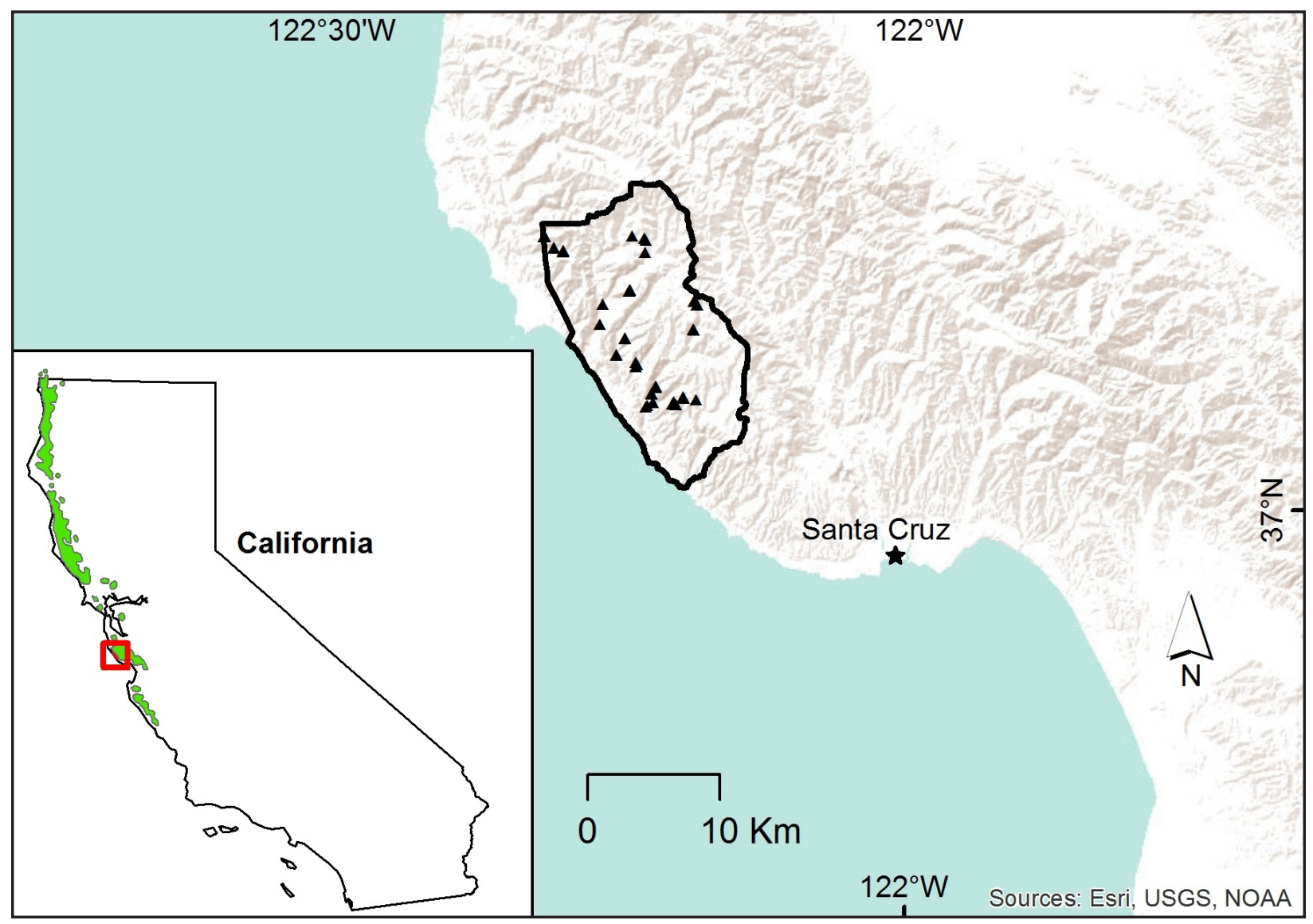

Figure 1. Fire history study area and sample locations in the Santa Cruz Mountains, California, USA. Inset illustrates the study area location in the context of the entire range of coast redwood (depicted in green).

\section{Data Collection Procedures}

We collected 70 cross-sections that were deemed suitable for analysis, 11 from living trees and remainder from stumps, logs, and snags. A cross-section was considered a viable sample if it exhibited at least two scars, providing a minimum of one fire interval to be included in the analysis. Fire scar specimens were identified and sampled on an opportunistic basis in order to obtain an adequate sample size (Brown and Baxter 2003, Stephens and Fry 2005). We extracted cross-sections (approximately $5 \mathrm{~cm}$ to $8 \mathrm{~cm}$ thick) using a chainsaw (Arno and Sneck 1977, McBride 1983). Less than $10 \%$ of the cross-sectional area of the boles of snags and live trees were removed, thus minimizing the potential for mechanical failure (Heyerdahl and McKay 2008). Both young and old specimens were selected in order to maximize the length and completeness of the temporal record (Farris et al. 2010). Wood exhibiting minimal decay and multiple externally visible fire scars were initially prioritized for sampling (Speer 2010). Sampling was extended to trees without visible scars as careful examination of cross-sections often revealed scars that were completely healed over and thus were not visible on exterior surfaces of the wood (Stephens et al. 2004). When possible, cross-sections were extracted from basal flutes or buttresses near the ground surface to provide the most complete inventory of scars (Brown and Swetnam 1994, Norman 2007, Norman et al. 2009). 
We prepared and analyzed fire-scarred specimens using dendrochronology techniques (Stokes and Smiley 1968, Arno and Sneck 1977, Orvis and Grissino-Mayer 2002). Samples were air dried and sanded with progressively finer sandpaper until the cellular structure within each annual growth ring, and the position of fire scars within the ring series, could be viewed clearly under a stereomicroscope with 7-45X magnification (Speer 2010). We identified 373 fire scars in 70 whole or partial cross-sections. Fire scars were identified by the presence of a gap (often charred) within the ring and subsequent overlapping curvilinear growth characteristic of the tree's healing pattern (McBride 1983). In addition, we used other fire-associated ring characteristics including traumatic resin ducts, double latewood, and growth releases to confirm the presence of a scar found elsewhere along the circumference of the cross-section (Brown and Swetnam 1994). We approximated the seasonality of fire occurrence by assessing the position of the scar within the annual growth ring (Caprio and Swetnam 1995).

Accurate cross-dating of redwoods is notoriously challenging due to the unusual ring patterns exhibited in coast redwoods such as missing, partial, and compressed rings (Fritz 1940, Brown and Swetnam 1994, Waring and O'Hara 2006, Lorimer et al. 2009). In their paper on growth ring analysis, Waring and O'Hara (2006) stated that: "[Cross-dating] is not practical (and perhaps not even possible) . . . [with] coast redwood." Recent advances in dendrochronology techniques may improve the ability of fire ecologists to cross-date fire scars (Carroll et al. 2014), but, at present, most studies rely on approximate fire dates as a means of characterizing the fire history of coast redwood forests (Stephens and Fry 2005). The process proved no less difficult in this case, and cross-dating was not successful. Consequently, individual trees (point samples) were used as the basic sample unit throughout this study and intervals from separate trees were not composited.
Of the 70 cross-sections that were analyzed, 51 provided floating fire scar sequences that allowed for analysis of undated interval data. Nineteen of the cross-sections, either extracted from live trees $(n=11)$ or with reliable harvest dates $(n=8)$, provided approximate fire dates based on ring counts. All dates were considered approximate as cross-dating was not conducted.

Intervals were calculated exclusively from scar to scar. The period from the tree origination date to the first fire scar was not used in this analysis (sensu Baker and Ehle 2001), as this interval cannot necessarily be considered a true fire interval, particularly for a species such as coast redwood that is not dependent on fire for recruitment (Lazzeri-Aerts and Russell 2014). All sampled scars were included in the analysis regardless of age, as we were relying on data from point samples rather than on composite data sets verified by cross-dating, and therefore early scars had value in describing the fire history of these individual trees.

For each cross-section extracted from recording trees, the point minimum, maximum, median, mean, and range of fire-return intervals were calculated. The single tree (point) mean fire-return interval was defined as the statistical average of all fire intervals in each individual sample and was calculated by recording the number of annual growth rings between each fire scar, summing the intervals, and then dividing this result by the total number of intervals. We calculated the grand mean FRI by taking the average across all individual tree estimates.

We used FHX2: Fire History Software (a DOS-based utility) to analyze the samples with approximate fire dates based on ring counts, including the calculation of the mean number of recorder years, as well as the analysis of the seasonality and fire-return interval data (Grissino-Mayer 2001). A chronology graph was created in the Graphics Module of the Fire History Analysis and Exploration System (FHAES) on a JAVA platform (www. frames.gov/fhaes). 
Comparisons between the three historical periods (1352 to 1848, 1849 to 1921, and 1922 to 2013) were conducted using descriptive statistics. In addition, the number of scars by $10-$ year increments was determined and a curvilinear regression analysis was conducted to assess the potential relationship between time period and the incidence of scarring.

\section{RESULTS}

\section{Comprehensive Fire Scar Data}

The grand mean fire-return interval (FRI) across all samples was $60.6 \mathrm{yr}$ with a range from $7.5 \mathrm{yr}$ to $518 \mathrm{yr}$ (SE 8.90). The median, which may be a more accurate measure of central tendency, was 40.1 yr. A frequency distribution of the FRI, divided into 10-year increments, illustrated a positive skew toward shorter return intervals (Figure 2). We found an equal percentage of intervals in the $\leq 10$ year and 11- to 20-year interval classes ( 1 to $10=21.1 \% ; 11$ to $20=21.4 \%$ ). Thirteen per- cent of the intervals fell within the 21 - to 30 year interval class while $11 \%$ of the intervals fell within the 31- to 40-year interval class. The longer interval classes encompassed the remaining $33 \%$ of the intervals. Although the longest interval class captured all intervals that exceeded 200 years, there were three intervals $(1.3 \%)$ that exceeded 300 years.

We were able to approximate seasonality of fire occurrence for 296 of the 373 (79.4\%) fire scars found in the study area. The majority of fire scars were detected in the latewood $(17.7 \%)$ and dormant $(53.4 \%)$ portions of the annual growth rings, indicating that most fires took place in the late summer, fall, or early winter. By contrast, we detected only $8 \%$ of the fires scars in the earlywood potions of annual growth rings.

\section{Approximately Dated Fire Scar Data}

We approximated scar dates from 11 samples that were extracted from live trees and 8 samples with definite harvest dates for a total

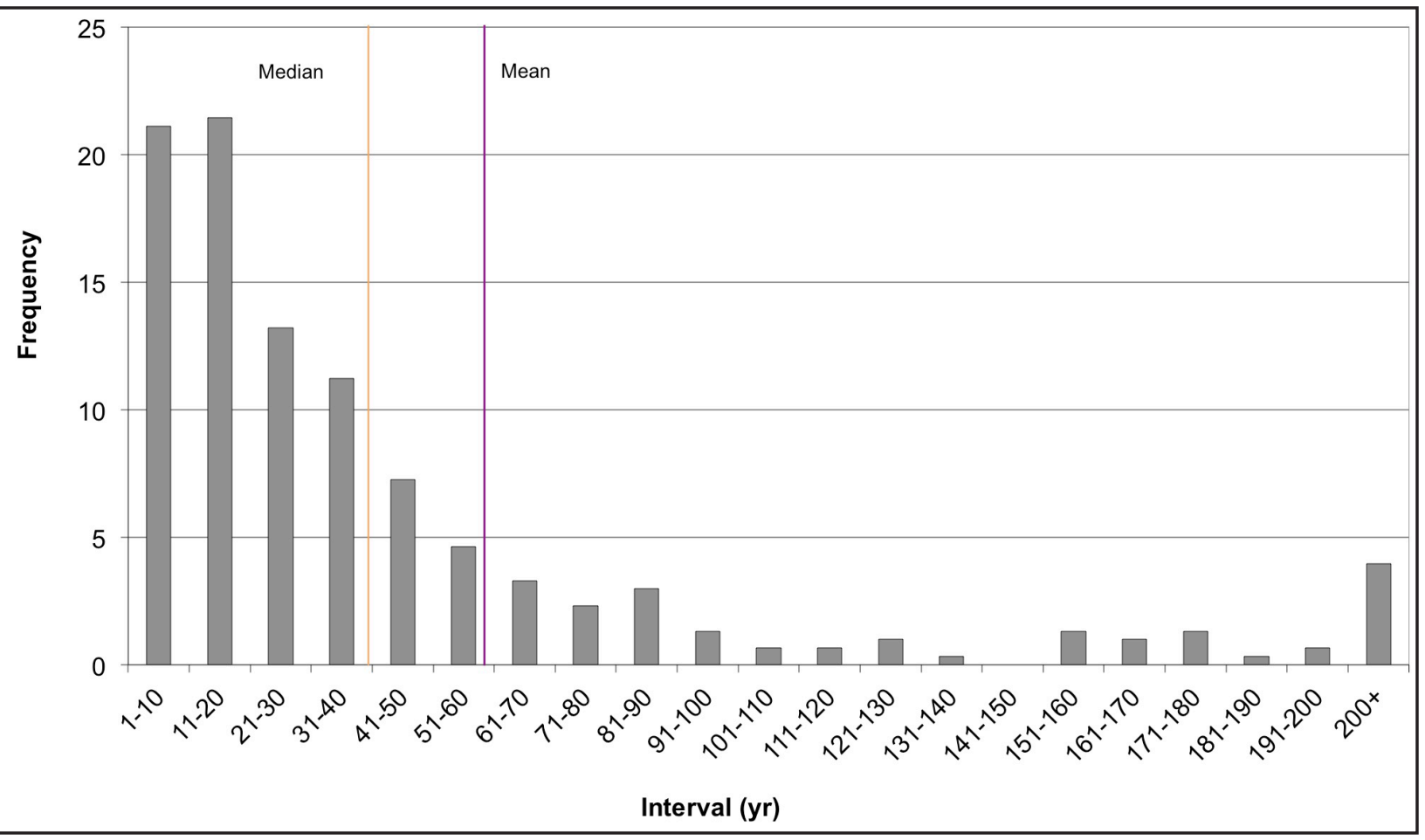

Figure 2. Fire-return interval frequency distribution in 10 -year increments for coast redwood trees in the Santa Cruz Mountains, California, USA $(n=303)$. 
of 19 samples. For these samples, 110 fires and 91 fire-return intervals were recorded from 4395 total recorder years. The range of years for samples was 1182 to 2013. The minimum FRI was $1 \mathrm{yr}$ and maximum interval was 188 yr. Point mean intervals for individual trees ranged from $10.4 \mathrm{yr}$ to $128 \mathrm{yr}$. The earliest fire scar indicated a fire date of 1352, although we considered approximations of early dates to be generally less reliable. The most recent date was 2009, presumably from the 3163 ha Lockheed Fire that occurred on 12 to 23 August of that year (Figure 3).

Curvilinear regression analysis on approximately dated samples indicated that the mean number of fire scars per 10-year time period began to increase in the $1770 \mathrm{~s}\left(\mathrm{R}^{2}=0.3407, P\right.$ $=0.0273)$. This trend continued until circa 1920, when the incidence of scarring peaked. This apparent increase in fire-return interval was temporary as scarring decreased after the 1930s (Figure 4).
The mean point FRI varied among the historical periods, with the pre-settlement period (1352 to 1849) exhibiting a relatively higher FRI than the other two periods (Table 1). There was no apparent difference between the number of fires during the settlement period (1849 to 1921) and the recent period (1922 to 2013), however. Distinctions between these periods were clouded by a high degree of variation.

\section{DISCUSSION}

Results from this study provide estimates of the fire-return interval for the southern range of the coast redwood forest that were generally longer than those found in previous research. The degree of variation among and within samples, however, suggests that any measure of central tendency may have limited practical use for land management planning.

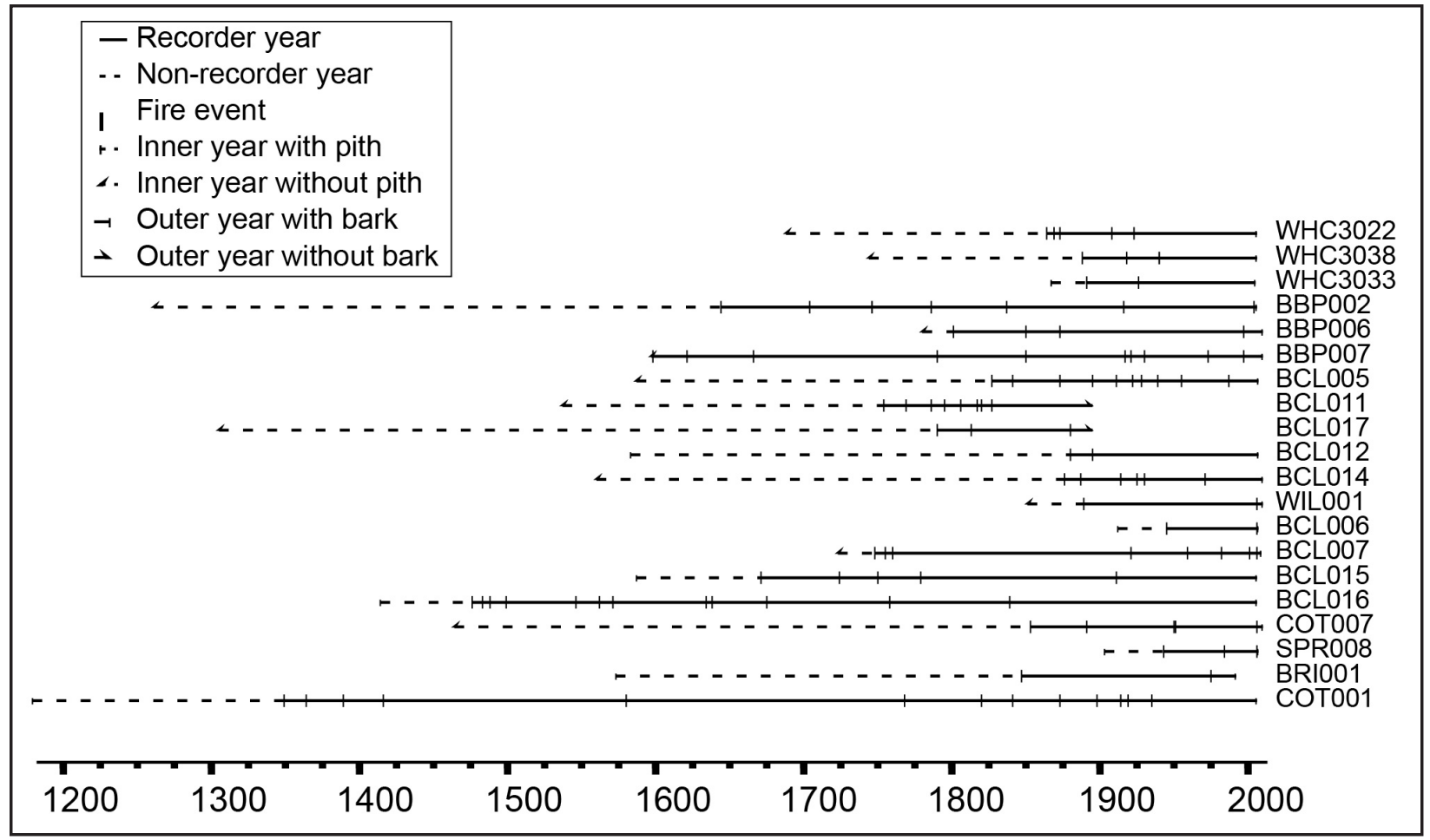

Figure 3. Chronology for approximately dated ring series and fire scars (1182 to 2013) in the Santa Cruz Mountains, California, USA $(n=19)$. Horizontal lines are individual fire scar samples and vertical ticks indicate fire scars. Null years are indicated by horizontal dotted lines and recorder years by horizontal solid lines. 


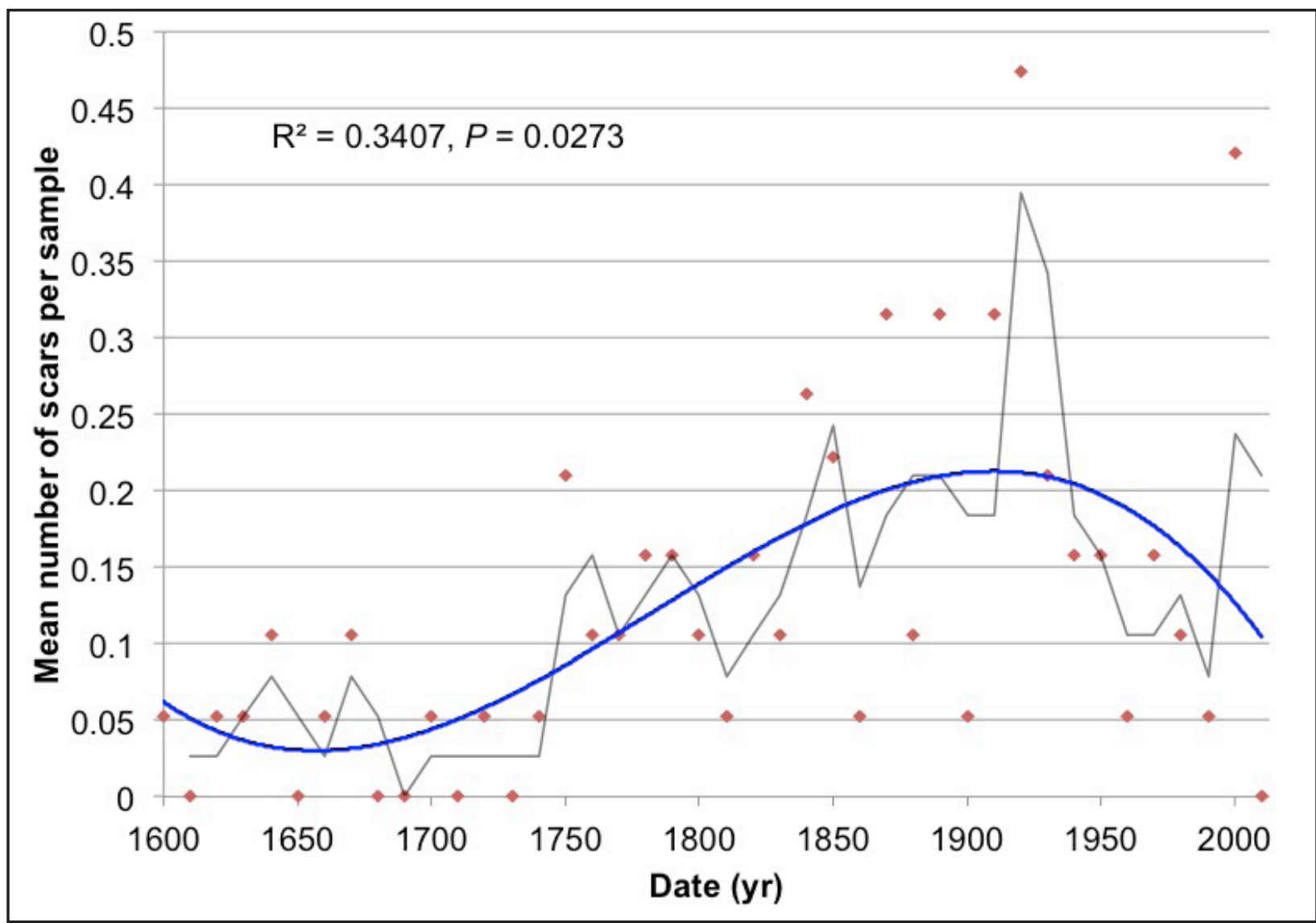

Figure 4. Fire scar frequency per 10-year periods (1600 to 2013) from 19 cross-sections. The gray trend line indicates a 2-period moving average. The blue trend line displays a cubic polynomial curve for which the $\mathrm{R}^{2}$ and $P$-value are displayed.

Table 1. Fire-return interval data for approximately dated fire scars by time period in the Santa Cruz Mountains, California, USA. SE $=$ standard error of the mean $(n=19)$.

\begin{tabular}{lcccccc}
\hline Time period & $\begin{array}{c}\text { Fire scars } \\
(\boldsymbol{n})\end{array}$ & $\begin{array}{c}\text { Intervals } \\
(\boldsymbol{n})\end{array}$ & $\begin{array}{c}\text { Mean FRI } \\
(\mathbf{y r})\end{array}$ & SE & $\begin{array}{c}\text { Median FRI } \\
(\mathbf{y r})\end{array}$ & $\begin{array}{c}\text { Range } \\
(\mathbf{y r})\end{array}$ \\
\hline $\begin{array}{l}\text { Pre-settlement } \\
(1352 \text { to } 1849)\end{array}$ & 49 & 44 & 43.3 & 6.90 & 26.5 & $185(3$ to 188$)$ \\
$\begin{array}{l}\text { Settlement } \\
(1850 \text { to } 1921)\end{array}$ & 36 & 23 & 30.7 & 6.18 & 23.0 & 124 (4 to 128) \\
$\begin{array}{l}\text { Recent } \\
(1922 \text { to } 2013)\end{array}$ & 27 & 24 & 32.3 & 5.93 & 22.5 & 123 (1 to 124) \\
\hline
\end{tabular}

The fire-return intervals estimated from our data were closest to Greenlee's (1983) composite mean FRI of 45.4 years for Big Basin Redwoods State Park, and were furthest from the $6.2 \mathrm{yr}$ to $23.0 \mathrm{yr}$ and $12.4 \mathrm{yr}$ to 16.3 yr FRIs found by Finney and Martin (1992) and Stephens and Fry (2005). Differing vege- tation mosaics, combined with both physiographic and microclimate variation between aforementioned study sites likely accounts for many of these discrepancies. Where more mesic conditions exist near the coast, Sequoia sempervirens tends to grow in continuous groves, and fires tend to be less frequent and 
intense due to relatively moist fuel conditions (Veirs 1985, Martin and Sapsis 1991, Heyerdahl et al. 2001). Seasonality of fire was consistent with the literature, with the prevalence of fire scars in the latewood, and with the dormant portions of the annual growth rings (Finney and Martin 1992, Brown and Baxter 2003, Stephens and Fry 2005, Norman 2007).

The historical FRI distribution from our study exhibited certain similarities to distributions from other fire history studies across the range of coast redwood. The majority of the intervals were relatively short, but the results from our study included a greater number of long intervals resulting in a longer mean FRI and more variability in the data set (Figure 5). The relatively large number of fire scars that were detected in the recent period was primarily a result of sampling methods, rather than a reflection of a higher number of fires during that period. More viable samples were available in the youngest wood, whereas older samples provided progressively less reliable fire scar data due to degradation.

Unlike many forest types in the western United States, fires in the coast redwood forests result primarily from anthropogenic, rather than natural, sources (van Wagtendonk and Cayan 2008). Spanish explorer accounts of Native American burning, as well as current research, suggests that indigenous tribes used fire extensively on the central coast, particularly near the coastline in the vicinity of Point Año Nuevo (Cuthrell 2013). An initial increase in fire occurrence immediately preceding the advent of non-native settlement of the region eventually gave way to diminished fire frequencies, most likely due to the implementation of more effective fire suppression campaigns, as illustrated by results from the settle-

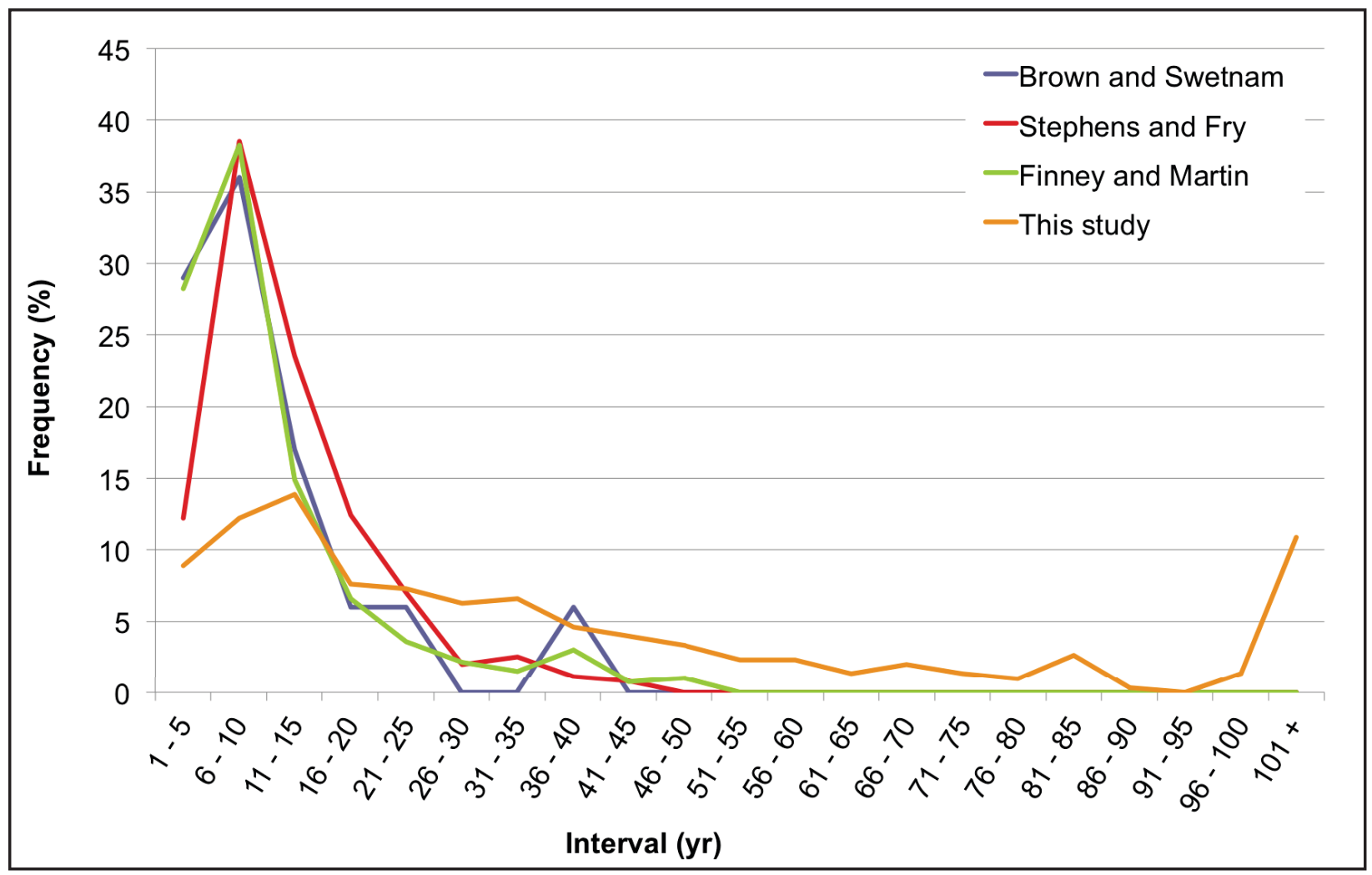

Figure 5. Fire history distributions from this study, Prairie Creek Redwoods State Park (Brown and Swetnam 1994), northeast Santa Cruz Mountains (Stephens and Fry 2005), and Annadel State Park (Finney and Martin 1992). Figure adapted from Norman et al. (2009). 
ment and recent periods. It is unlikely that this increase was a result of naturally ignited fire, as lightning fires are extremely limited in the region (Keeley 2005). It is likely that both pre-colonial and historical land use practices and burning patterns in this study area were highly temporally and spatially variable, creating a mosaic of fire regime characteristics dispersed across the landscape (Lightfoot and Parrish 2009). Greater resolution on the topic of the influence of cultural burning practices, combined with more accurate dating than this study provides, may provide more definitive fire histories in the future.

Knowledge of the coast redwood fire regime is important in order for resource managers to assess the appropriate role of fire in modern coast redwood forests. However, it is challenging for managers who wish to reintroduce fire as a disturbance process into redwood ecosystems to find a useful set of reference fire regime attributes on which to base restoration objectives. If anthropogenic burning practices affected the landscape by increasing biodiversity and influencing forest structure and composition, then prescribed burning could serve as a proxy for both pre-colonial and historical ignitions, now largely ab- sent from the landscape (Finney and Martin 1989, Brown et al. 1999, Stephens and Fry 2005). This study suggests that managing fire for regularity based on a mean or median fire-return interval and subsequent fire-return interval departure (Caprio et al. 2002) may not be appropriate, as these metrics are only marginally illustrative of the variability of the redwood fire regime in this area. One restoration model that may prove useful is the practice of restoring cultural landscapes in which management activities are centered on incorporating components of traditional resource and environmental management (Fowler and Lepofsky 2011). This model has been successfully implemented in Redwood National Park, California, where the Bald Hills are burned regularly to maintain the ethnographic landscape (Underwood et al. 2003). In addition, opportunities for patch mosaic burning should be investigated as a means for maintaining both spatial and temporal variability of fires in this biome (Brockett et al. 2001, Stephens and Fry 2005). Resource managers will likely need to employ a suite of fire management strategies in coast redwood forests that are firmly grounded in a context of adaptive management, regardless of the restoration model used.

\section{ACKNOWLEDGEMENTS}

We would like to thank Big Basin Redwoods State Park, Big Creek Lumber, the Sempervirens Fund, Skylark Ranch, Swanton Pacific Ranch, and the organizations that jointly manage the San Vicente Redwoods for allowing us access to their lands for our fieldwork and for sharing their extensive knowledge of land use history in the area. We also thank C. Striplen from the San Francisco Estuary Institute for his countless hours spent assisting in the field and in the lab.

\section{LITERATURE CITED}

Adams, K. 1969. The redwoods. Popular Library, New York, New York, USA.

Arno, S.F., and K.M. Sneck. 1977. A method for determining fire history in coniferous forests of the mountain west. USDA Forest Service General Technical Report INT-GTR-42, Intermountain Forest and Range Experiment Station, Ogden, Utah, USA.

Baker, W.L., and D. Ehle. 2001. Uncertainty in surface-fire history: the case of ponderosa pine forests in the western United States. Canadian Journal of Forest Research 31: 1205-1226. doi: $10.1139 / \mathrm{x} 01-046$ 
Biswell, H.H. 1989. Prescribed burning in California wildlands vegetation management. University of California Press, Berkeley, USA.

Brockett, B.H., H.C. Briggs, and B.W. van Wilgen. 2001. A patch mosaic burning system for conservation areas in southern African savannas. International Journal of Wildland Fire 10: 169-183. doi: 10.1071/WF01024

Brown, A.K. 1966. Sawpits in the Spanish redwoods 1787-1849. San Mateo County Historical Association, San Mateo, California, USA.

Brown, P.M. 2007. What was the role of fire in coast redwood forests? Pages 215-218 in: R.B. Standiford, G.A. Giusti, Y. Valachovic, W.J. Zielinski, and M.J. Furniss, technical editors. Proceedings of the redwood region forest science symposium: what does the future hold? USDA Forest Service General Technical Report PSW-GTR-194, Pacific Southwest Research Station, Albany, California, USA.

Brown, P.M., and W.T. Baxter. 2003. Fire history in coast redwood forests of the Mendocino Coast, California. Northwest Science 77: 147-158.

Brown, P.M., M.W. Kaye, and D. Buckley. 1999. Fire history in Douglas-fir and coast redwood forests at Point Reyes National Seashore, California. Northwest Science 73: 205-216.

Brown, P.M., and T.W. Swetnam. 1994. A cross-dated fire history from coast redwood near Redwood National Park, California. Canadian Journal of Forest Research 24: 21-31. doi: 10.1139/x94-004

California Department of Water Resources. 2003. Ground water basins in California. Bulletin 118, California Department of Water Resources, Sacramento, California, USA.

Caprio, A.C., C. Conover, M. Kiefer, and P. Lineback. 2002. Fire management and GIS: a framework for identifying and prioritizing fire planning needs. Pages 102-113 in: N.G. Sugihara, M.E. Morale, and T.J. Morales, editors. Proceedings of the symposium: fire in California ecosystems: integrating ecology, prevention and management. Miscellaneous Publication No. 1, Association for Fire Ecology, Eugene, Oregon, USA.

Caprio, A.C., and T.W. Swetnam. 1995. Historic fire regimes along an elevational gradient on the west slope of the Sierra Nevada. Pages 173-179 in: J.K. Brown, R.W. Mutch, C.W. Spoon, and R.H. Wakimoto, editors. Proceedings of the symposium: fire in wilderness and park management. USDA Forest Service General Technical Report INT-320, Intermountain Research Station, Ogden, Utah, USA.

Carroll A.L., Sillett S.C., Kramer R.D. 2014. Millennium-scale crossdating and inter-annual climate sensitivities of standing California redwoods. PLoS ONE 9(7): e102545. doi: 10.1371/ journal.pone.0102545

Clar, C.R. 1959. California government and forestry: from Spanish days until the creation of the Department of Natural Resources in 1927. State of California Department of Natural Resources Division of Forestry, Sacramento, USA.

Cooper, W.S. 1917. Redwoods, rainfall and fog. Plant World 20: 79-189.

Cuthrell, R.Q. 2013. An eco-archaelogical study of late Holocene indigenous foodways and landscape management practices at Quiroste Valley Cultural Preserve. Dissertation, University of California, Berkeley, USA.

Davis, F.W. and M.I. Borchert. 2006. Central Coast Bioregion. Pages 321-349 in: N.G. Sugihara, J.W. van Wagtendonk, K.E. Shaffer, J. Fites-Kaufman, and A.E. Thode, editors. Fire in California's ecosystems. University of California Press, Berkeley, USA. doi: 10.1525/california/9780520246058.003.0014

Dawson, T.E. 1998. Fog in the California redwood forest: ecosystem inputs and use by plants. Oecologia 117: 476-485. doi: 10.1007/s004420050683 
Farris, C.A., C.H. Baisan, D.A. Falk, S.R. Yool, and T.W. Swetnam. 2010. Spatial and temporal corroboration of a fire-scar-based fire history in a frequently burned ponderosa pine forest. Ecological Applications 20: 1598-1614. doi: 10.1890/09-1535.1

Finney, M.A., and R.E. Martin. 1989. Fire history in a Sequoia sempervirens forest at Salt Point State Park, California. Canadian Journal of Forest Research 19: 1451-1457. doi: 10.1139/ x89-221

Finney, M.A., and R.E. Martin. 1992. Short fire intervals recorded by redwoods at Annadel State Park, California. Madroño 39: 251-262.

Fowler, C.S., and D. Lepofsky. 2011. Traditional resource and environmental management. Pages 285-304 in: E.N. Anderson, D. Pearsall, E. Hunn, and N. Turner, editors. Ethnobiology. Wiley-Blackwell, New York, New York, USA. doi: 10.1002/9781118015872.ch17

Fritz, E. 1940. Problems in dating rings of California coast redwood. Tree-Ring Bulletin 6: 1921.

Gordon, B.L. 1996. Monterey Bay area: natural history and cultural imprints. The Boxwood Press, Pacific Grove, California, USA.

Greenlee, J.M. 1983. Vegetation, fire history, and fire potential of Big Basin Redwoods State Park, California. Dissertation, University of California, Santa Cruz, USA.

Greenlee, J.M., and J.H. Langenheim. 1990. Historic fire regimes and their relation to vegetation patterns in the Monterey Bay area of California. American Midland Naturalist 124: 239-253. doi: $10.2307 / 2426173$

Grissino-Mayer, H.D. 2001. FHX2 software for analyzing temporal and spatial patterns in fire regimes from tree-rings. Tree-Ring Research 57: 115-124.

Heyerdahl, E.K., L.B. Brubaker, and J.K. Agee. 2001. Spatial controls of historical fire regimes: a multiscale example from the Interior West, USA. Ecology 82: 660-678. doi: 10.1890/0012-9658(2001)082[0660:SCOHFR]2.0.CO;2

Heyerdahl, E.K., and S.J. McKay. 2008. Condition of live fire-scarred ponderosa pine eleven years after removing partial cross-sections. Tree-Ring Research 64: 61-64. doi: $10.3959 / 2007-21.1$

Jacobs, D.F., D.W. Cole, and J.R. McBride. 1985. Fire history and perpetuation of natural coast redwood ecosystems. Journal of Forestry 83: 494-497.

Johnstone, J.A., and T.E. Dawson. 2010. Climatic context and ecological implications of summer fog decline in the coast redwood region. Proceedings of the National Academy of Sciences 107: 4533-4538. doi: 10.1073/pnas.0915062107

Keeley, J.E. 2002. Native American impacts on fire regimes of the California coastal ranges. Journal of Biogeography 29: 303-320. doi: 10.1046/j.1365-2699.2002.00676.x

Keeley, J.E. 2005. Fire history of the San Francisco Bay region and implications for landscape patterns. International Journal of Wildland Fire 14: 285-296. doi: 10.1071/WF05003

Kelly, P.E., E.R. Cook, and D.W. Larson. 1994. A 1397-year tree-ring chronology of Thuja occidentalis from cliff faces of the Niagara Escarpment, southern Ontario, Canada. Canadian Journal of Forest Research 24: 1049-1057. doi: 10.1139/x94-137

Lazzeri-Aerts, R., and W. Russell. 2014. Survival and recovery following wildfire in the southern range of the coast redwood forest. Fire Ecology 10(1): 43-55. doi: 10.4996/fireecology. 1001043

Lightfoot, K.G., and O.T. Parrish. 2009. California Indians and their environment. University of California Press, Berkeley, USA. 
Lorimer, C.G., D.J. Porter, M.A. Madej, J.D. Stuart, S.D. Veirs, S.P. Norman, K.L. O’Hara, and W.J. Libby. 2009. Presettlement and modern disturbance regimes in coast redwood forests: implications for the conservation of old-growth stands. Forest Ecology and Management 258: 1038-1054. doi: 10.1016/j.foreco.2009.07.008

Martin, R.E., and D.B. Sapsis. 1991. Fires as agents of biodiversity: pyrodiversity promotes biodiversity. Pages 150-157 in: R.R. Harris, D.C. Erman, H.M. Kerner, editors. Proceedings of the symposium on biodiversity of northwestern California, 28-30 October 1991, Santa Rosa, California, USA. Wildland Resources Center, Division of Agriculture and Natural Resources, University of California, Berkeley, USA.

McBride, J.R. 1983. Analysis of tree-rings and fire scars to establish fire history. Tree-Ring Bulletin 43: 51-68.

Milliken, R.T., L.H. Shoup, and B.R. Ortiz. 2009. Ohlone/Costanoan Indians of the San Francisco peninsula and their neighbors, yesterday and today. National Park Service, Golden Gate National Recreation Area, San Francisco, California, USA.

Norman, S.P. 2007. A 500-year record of fire from a humid coast redwood forest: a report to Save the Redwoods League. Save the Redwoods League, San Francisco, California, USA.

Norman, S.P., J.M. Varner, L. Arguello, and S. Underwood. 2009. Fire and fuels management in coast redwood forests. Report Number 06-2-1-59. USDA-USDI Joint Fire Science Project, National Interagency Fire Center, Boise, Idaho, USA.

Orvis, K., and H.D. Grissino-Mayer. 2002. Standardizing the reporting of abrasive papers used to surface tree-ring samples. Tree-Ring Research 58: 47-50.

Ramage, B.S., K.L. O'Hara, and B.T. Caldwell. 2010. The role of fire in the competitive dynamics of coast redwood forests. Ecosphere 1(6): 1-18. doi: 10.1890/ES10-00134.1

Robichaud, A., and C.P. Laroque. 2008. Dendroarchaeology in southwestern Nova Scotia and the construction of a regional red spruce chronology. Tree Ring Research 64: 17-25. doi: 10.3959/2007-9.1

Sawyer, J.O., S.C. Silette, J.H. Popenoe, A. LaBanca, T. Sholars, D.L. Largent, F. Euphrat, R.F. Noss, and R. van Pelt. 2000. History of redwood and redwood forests. Pages 7-38 in: R.F. Noss, editor. The redwood forest: history, ecology, and conservation of the coast redwoods. Island Press, Washington D.C., USA.

Speer, J.H. 2010. Fundamentals of tree-ring research. University of Arizona Press, Tucson, USA.

Stephens, S.L., and D.L. Fry. 2005. Fire history in coast redwood stands in the northeastern Santa Cruz Mountains, California. Fire Ecology 1(1): 2-19. doi: 10.4996/fireecology.0101002

Stephens, S.L., D.D. Piirto, and D.F. Caramagno. 2004. Fire regimes and resultant forest structure in the native Año Nuevo Monterey pine (Pinus radiata) forest, California. American Midland Naturalist 152: 25-36. doi: 10.1674/0003-0031(2004)152[0025:FRARFS]2.0.CO;2

Stewart, O.C. 2002. Forgotten fires: Native Americans and the transient wilderness. University of Oklahoma Press, Norman, USA.

Stokes, M.A., and T.L. Smiley. 1968. An introduction to tree-ring dating. University of Chicago Press, Illinois, USA.

Stuart, J.D. 1987. Fire history of an old-growth forest of Sequoia sempervirens (Taxodiaceae) forest in Humboldt Redwoods State Park, California. Madroño 34: 128-141.

Swanton Pacific Ranch. 2011. S wanton Pacific Ranch Management Plan. California Polytechnic State University, San Luis Obispo, California, USA. 
Underwood, S., L. Arguello, and N. Siefkin. 2003. Restoring ethnographic landscapes and natural elements in Redwood National Park. Ecological Restoration 21: 278-283. doi: 10.3368/ er.21.4.278

van Wagtendonk, J.W., and D.R. Cayan. 2008. Temporal and spatial distribution of lightning strikes in California in relation to large-scale weather patterns. Fire Ecology 4(1): 34-56. doi: 10.4996/fireecology.0401034

Veirs, S.D. 1985. Coastal redwood fire ecology and prescribed fire management. Proceedings of a workshop, 15-16 October 1984, Redwood National Park, Arcata, California, USA. Cooperative Park Studies Unit, Redwood National Park, Crescent City, California, USA.

Waring, K.M., and K.L. O'Hara. 2006. Estimating relative error in growth ring analyses of second-growth coast redwood (Sequoia sempervirens). Canadian Journal of Forest Research 36: 2216-2222. doi: 10.1139/x06-127 